\title{
The Efficacy and Safety of Procedural Sedoanalgesia with Midazolam and Ketamine in Pediatric Hematology
}

\section{Çocuk Hematolojide Midazolam ve Ketaminle Uygulanan İşlemsel Sedoanaljezinin Etkinliği ve Güvenilirliği}

Sema Aylan Gelen, Nazan Sarper, Uğur Demirsoy, Emine Zengin, Esma Çakmak

Kocaeli University Faculty of Medicine Hospital, Department of Pediatrics, Division of Pediatric Hematology, Kocaeli, Turkey

\begin{abstract}
:
Objective: The aim of this study is to investigate the efficacy and safety of sedoanalgesia performed outside the operating room by pediatricians trained in advanced airway management and life support.

Materials and Methods: Midazolam and ketamine were administered consecutively by intravenous route under cardiorespiratory monitoring for painful procedures of pediatric hematology.

Results: A total of 115 patients had 237 sedoanalgesia sessions. Sedation time was $24.02 \pm 23.37 \mathrm{~s}$ and sedation success was $92.5 \%$ (Ramsay scores of $\geq 5$ ). Patient satisfaction was high. The recovery time was $28.81 \pm 14.4 \mathrm{~min}$. Although statistically significant $(\mathrm{p}<0.01)$ increases in systolic and diastolic blood pressure, heart rate, and respiratory rate were observed without clinical importance, they improved without any intervention. No severe adverse events were observed.
\end{abstract}

Conclusion: Sedoanalgesia with intravenous midazolam and ketamine for pediatric hematology and oncology patients' painful minor invasive procedures performed in an optimally equipped setting outside the operating room by pediatricians trained and certificated in advanced airway management and life support is effective and safe.

Keywords: Sedoanalgesia, Ketamine, Midazolam, Invasive procedure

Öz:

Amaç: Çalışmamızın amacı, ileri yaşam desteği konusunda eğitimli pediatristler tarafından ameliyathane dışında gerçekleştirilen ağrılı işlemlerde uygulanan sedoanaljezinin etkinliği ve güvenilirliğinin araştırılmasıdır.

Gereç ve Yöntemler: Pediatrik hematolojinin ağrılı işlemlerinde, kalp-solunum monitorizasyonu yapılarak midazolam ve ketamin ardarda intravenöz yolla uygulanmıştır.

Bulgular: Yüz on beş hastaya 237 sedoanaljezi uygulandı. Sedasyon süresi $24,02 \pm 23,37$ saniye, sedasyon başarısı $\% 92,5$ idi (Ramsay skoru $\geq 5$ ). Hasta memnuniyeti yüksekti. Uyanma süresi $28,81 \pm 14,45$ dakika idi. İşlemler sırasında sistolik ve diastolik tansiyon artışı, kalp hızı ve solunum sayısında artış istatistiksel olarak anlamlı ( $<<0,01)$ bulunmasına rağmen, klinik olarak anlamlı değildi ve herhangi bir girişim yapılmadan düzeldi. Ciddi yan etki gözlenmedi.

Sonuç: Pediatrik hematoloji ve onkoloji hastalarının ağrılı minör invazif işlemlerinde, intravenöz midazolam ve ketamin ile sedoanaljezi; uygun donanıma, monitorizasyona sahip bir ortamda ve ileri yaşam desteği konusunda eğitimli ve sertifikalı pediatristler tarafından gereğinde yapıldığında, ameliyathane dışında da etkin ve güvenilirdir.

Anahtar Sözcïkler: Sedoanaljezi, Ketamin, Midazolam, İnvazif işlem

Address for Correspondence: Sema Aylan GELEN, M.D.,

Kocaeli University Faculty of Medicine Hospital, Department of Pediatrics, Division of Pediatric Hematology, Kocaeli, Turkey

Phone: +90 5325962554 E-mail: semaylan@hotmail.com

Received/Gelis tarihi : April 10, 2014

Accepted/Kabul tarihi : October 17, 2014 


\section{Introduction}

Lumbar puncture, bone marrow aspiration/biopsy, and intrathecal therapy are painful procedures. In patients with leukemia, traumatic lumbar puncture due to poor patient stabilization is a diagnostic dilemma and may cause seeding of the blasts into the cerebrospinal fluid from circulation $[1,2]$. The burden of the procedure under inadequate sedoanalgesia can lead to refusal of the diagnostic procedure or treatment [3].

In this study, the aim was to evaluate the efficacy and safety of procedural sedoanalgesia performed by pediatricians and hematologists trained in advanced airway management and life support.

\section{Materials and Methods}

This prospective study was planned by pediatric hematologists. The ethics committee of the center approved the study and written informed consent was obtained. Physicians were trained in advanced life support and had a proficient command of the characteristics and pharmacology of the sedatives/analgesics. One of the physicians performed the invasive procedure, and the other administered the drugs, assisted in patient monitoring, and recorded the vital signs and sedation and recovery times. During the lumbar punctures and intrathecal therapy a nurse assisted in proper positioning of the patient.

Sedation time (the period to induce sedation after the administration of both drugs) and recovery time (the period until the patient was awake with age-appropriate behavior and age-appropriate oriented responses to verbal and motor stimuli after the procedure was accomplished) were recorded.

Sedation was initiated with midazolam $(0.1 \mathrm{mg} / \mathrm{kg} /$ dose by slow intravenous infusion, maximum $10 \mathrm{mg}$ ) and continued with ketamine (1 $\mathrm{mg} / \mathrm{kg} /$ dose by slow intravenous bolus, maximum $100 \mathrm{mg}$ ). Level of sedation was assessed according to the modified Ramsay scale (Table 1). When the score was 5 or 6 , which was considered as satisfactory sedation, the procedure was initiated. A score of below 5 was rated as unsatisfactory sedation. Patients were followed by the study nurse for $4 \mathrm{~h}$ for any adverse events. Severe adverse events were defined as cardiovascular collapse, airway and respiratory events including hypoxemia requiring resuscitation, and allergic reactions.

\section{Statistical Analysis}

Statistical analysis was performed using SPSS 2.0 (SPSS Inc., Chicago, IL, USA). For evaluation of demographic characteristics descriptive statistics were used, and for intergroup comparison of the parameters that had normal distribution the paired samples t-test was used.

\section{Results}

Between May 2012 and May 2013, a total of 237 invasive procedures (bone marrow biopsy/aspiration, intrathecal chemotherapy) were performed in 115 children $(9.4 \pm 4.5$ years, range: 10 months to 19.5 years) with sedoanalgesia.

Median sedation time was $24.02 \pm 23.37$ s (range: $1-300$ s). Median recovery time was $28.81 \pm 14.45 \mathrm{~min}$ (range: $5-90$ $\min )$. In $87 \%(n=207)$ of the sessions no additional dose was administered. Due to prolongation of the procedures or unsatisfactory sedation 1 additional dose of midazolam, 1 additional dose of ketamine, and 2 additional doses of ketamine were administered in 2 (0.8\%), 29 (12.2\%), and 1 $(0.8 \%)$ of the sedoanalgesia sessions, respectively. Out of 32 additional doses, 17 (53\%) were administered due to multiple painful procedures in the same session.

Oxygen saturation was over $90 \%$ in all the patients during sedation and at recovery. There was no apnea, respiratory depression, or need for assisted ventilation/intubation. None of the patients required flumazenil administration. No severe adverse events were observed. Vital signs are shown in Table 2. A significant increase in systolic and diastolic blood pressure, heart rate, and respiratory rate was observed during sedation and when the procedure was completed compared to baseline values $(p<0.01)$. However, these increases were not clinically significant, and after recovery, they returned to reference values $(\mathrm{p}<0.01)$. There was hypersalivation during sedation, when the procedure was completed, and when awake in $16.9 \%, 24.5 \%$, and $5.1 \%$ of the sessions, respectively $(\mathrm{p}<0.01)$. Simply wiping the secretions was enough; no aspiration was required. After the procedures in $6.8 \%(n=16), 5.1 \%(n=12)$, $1.7 \%(n=4)$, and $1.3 \%(n=3)$ of the sessions, hallucinations, vomiting, agitation, and pain at the procedure site were respectively recorded, but patients recovered without any therapeutic intervention. Hallucinations were seen during recovery but they were transient and self-limited. The overall

Table 1. Sedation score (modiŞed Ramsay score).

\begin{tabular}{|l|l|}
$\begin{array}{l}\text { Sedation } \\
\text { Level }\end{array}$ & Description of Clinical Status \\
\hline 1 & Fully awake, anxious \\
2 & Calm, adequate cooperation \\
\hline 3 & Arousable to verbal commands \\
\hline 4 & $\begin{array}{l}\text { Arousable to mild stimulation/vigorous } \\
\text { reaction to painful stimulus } \\
\text { Slow/incomplete reaction to painful physical } \\
\text { stimulation }\end{array}$ \\
\hline 6 & \begin{tabular}{l} 
No reaction to painful stimulation \\
\hline
\end{tabular}
\end{tabular}


Table 2. Cardiovascular parameters, respiratory rate, and hypersalivation in invasive procedures under midazolam/ ketamine sedoanalgesia.

\begin{tabular}{|c|c|c|c|c|}
\hline & Before Sedation & During Sedation & Procedure Completed & When Awake \\
\hline BPsys (mmHg) & $118.4 \pm 14.5$ & $124.4 \pm 16.3$ & $121.9 \pm 16.9$ & $113.7 \pm 14.8$ \\
\hline BPdia (mmHg) & $69.1 \pm 12.7$ & $77.1 \pm 13.2$ & $73.9 \pm 13$ & $67.2 \pm 11.8$ \\
\hline Heart rate (bpm) & $115.6 \pm 21.7$ & $124.9 \pm 21.1$ & $123.3 \pm 20.3$ & $113.8 \pm 20.5$ \\
\hline $\begin{array}{l}\text { Respiratory rate } \\
\text { (bpm) }\end{array}$ & $21.7 \pm 6.5$ & $22.9 \pm 6.8$ & $23.7 \pm 7$ & $21.5 \pm 6.3$ \\
\hline Hypersalivation & $1(0.4 \%)$ & $40(16.9 \%)$ & $58(24.5 \%)$ & $12(5.1 \%)$ \\
\hline
\end{tabular}

BPsys/BPdia: Systolic/diastolic blood pressure, bpm: beats per minute. Values are given as means.

adverse event rate was $14.8 \%(\mathrm{n}=35)$. Sedation was successful in $92.5 \%(\mathrm{n}=219)$ of the procedures. All the procedures were completed successfully and all the outpatients could be discharged on the same day. Patient satisfaction was high; when painful procedures were repeated all the patients and/or caregivers preferred the same sedoanalgesia.

\section{Discussion}

In developing countries during painful procedures many centers perform no sedoanalgesia due to limited numbers of anesthesiologists, busy operation rooms, and inadequate training in sedoanalgesia, advanced airway management, and life support [4]. In many studies, it has been shown that sedation and analgesia during painful procedures were administered with equally good results by pediatricians who had received advanced life support training $[5,6,7,8]$.

When midazolam and ketamine are used alone, respiratory depression with midazolam and dysphoric reactions (irritability, depression, etc.) with ketamine may occur. When midazolam is used with ketamine, faster analgesia, amnesia, and fewer side effects occur $[9,10,11]$. Oxygen desaturation may increase with addition of high-dose midazolam [12]. Therefore, additional doses of ketamine are preferred. In some previous studies with midazolam and ketamine the incidence of oxygen desaturation was between $4.8 \%$ and $12 \%$, whereas Ozdemir et al. reported no oxygen desaturation $[7,13,14,15,16]$. In the present study none of the patients' oxygen saturation dropped below $90 \%$. Compared to propofol, the combination of ketamine and midazolam was associated with less hypoxemia $[13,14]$.

In recent reports, similar to our findings, a significant increase in cardiovascular parameters was seen due to ketamine's sympathomimetic action via inhibition of catecholamine reuptake, but these parameters returned to baseline values at recovery and no treatment was required $[2,14,15,16,17]$.
In other published studies the sedation time was similar to that of the present study $[2,14,16]$. Parker et al. showed that more than $70 \%$ of the patients woke up in $30 \mathrm{~min}$, similar to our result [9]. Short sedation and recovery time seems a good feature of the drug combination.

Overall adverse event rate in our study was comparable to those of some other studies $[18,19,20]$. Ketamine may cause airway obstruction, laryngospasm, and aspiration by increasing tracheal and bronchial secretions. Agents such as atropine and glycopyrrolate can be used to reduce the increased secretions $[15,21,22]$. The hypersalivation rate was higher compared to those in the literature; this may be due to no atropine or glycopyrrolate administration. Prone position during and after the procedure prevented obstruction of the airway and aspiration was not required.

Venipuncture is another painful procedure for outpatient children, but oral, nasal, and rectal administrations of midazolam can provide slower sedation and this may cause a delay in the procedure. The intramuscular route is also painful and may require additional injections. With the intravenous route, sedoanalgesia can be achieved faster and, if necessary, additional doses and drugs for cardiopulmonary resuscitation can be administered easily.

\section{Conclusion}

With adherence to the published guidelines, sedoanalgesia with intravenous midazolam and ketamine performed by two physicians, trained in airway management and life support, in an optimally equipped setting outside the operating room is safe and efficient. Sedoanalgesia reduces the physical and psychological trauma of the invasive procedures for the patients, parents, and physicians and increases the success of the procedures. 
Concept: Nazan Sarper, Design: Nazan Sarper, Data Collection or Processing: Sema Aylan Gelen, Uğur Demirsoy, Emine Zengin Esma Çakmak, Analysis or Interpretation: Sema Aylan Gelen, Literature Search: Sema Aylan Gelen, Nazan Sarper, Writing: Sema Aylan Gelen, Nazan Sarper.

Conflict of Interest: The authors of this paper have no conflicts of interest, including specific financial interests, relationships, and/or affiliations relevant to the subject matter or materials included.

\section{References}

1. Maurizi P, Russo I, Rizzo D, Chiaretti A, Coccia P, Attina G, Ruggiero A, Riccardi R. Safe lumbar puncture under analgosedation in children with acute lymphoblastic leukemia. Int J Clin Oncol 2014;19:173-177.

2. Meyer S, Aliani S, Graf N, Reinhard H, Gottschling S. Sedation with midazolam and ketamine for invasive procedures in children with malignancies and hematological disorders: a prospective study with reference to the sympathomimetic properties of ketamine. Pediatr Hematol Oncol 2003;20:291301.

3. Sitaresmi MN, Mostert S, Schook RM, Sutaryo, Veerman AJ. Treatment refusal and abandonment in childhood acute lymphoblastic leukemia in Indonesia: an analysis of causes and consequences. Psychooncology 2010;19:361-367.

4. Iannalfi A, Bernini G, Caprilli S, Lippi A, Tucci F, Messeri A. Painful procedures in children with cancer: comparison of moderate sedation and general anesthesia for lumbar puncture and bone marrow aspiration. Pediatr Blood Cancer 2005;45:933-938.

5. American Society of Anesthesiologists Task Force on Sedation and Analgesia by Non-Anesthesiologists. Practice guidelines for sedation and analgesia by non-anesthesiologists. Anesthesiology 2002;96:1004-1017.

6. Pitetti RD, Singh S, Pierce MC. Safe and efficacious use of procedural sedation and analgesia by nonanesthesiologists in a pediatric emergency department. Arch Pediatr Adolesc Med 2003;157:1090-1096.

7. Borker A, Ambulkar I, Gopal R, Advani SH. Safe and efficacious use of procedural sedation and analgesia by nonanesthesiologists in a pediatric hematology-oncology unit. Indian Pediatr 2006;43:309-314.

8. Monroe KK, Beach M, Reindel R, Badwan L, Couloures KG, Hertzog JH, Cravero JP. Analysis of procedural sedation provided by pediatricians. Pediatr Int 2013;55:17-23.

9. Parker RI, Mahan RA, Guigliano D, Parker MM. Efficacy and safety of intravenous midazolam and ketamine as sedation for therapeutic and diagnostic procedures in children. Pediatrics 1997;99:427-431.
10. Pellier I, Mongrial JP, Le Moine P, Rod B, Rialland X, Granry JC. Use of intravenous ketamine-midazolam association for pain procedures in children with cancer: a prospective study. Paediatr Anaesth 1999;9:61-68.

11. Marx CM, Stein J, Tyler MK, Nieder ML, Shurin SB, Blumer JL. Ketamine-midazolam versus meperidine-midazolam for painful procedures in pediatric oncology patients. J Clin Oncol 1997;1:94-102.

12. Cheuk DK, Wong WH, Ma E, Lee TL, Ha SY, Lau YL, Chan GC. Use of midazolam and ketamine as sedation for children undergoing minor operative procedures. Support Care Cancer 2005;13:1001-1009.

13. Godoy ML, Pino AP, Córdova LG, Carrasco OJA, Castillo MA. Sedation and analgesia in children undergoing invasive procedures. Arch Argent Pediatr 2013;111:22-28.

14. Gottschling S, Meyer S, Krenn T, Reinhard H, Lothschuetz D, Nunold H, Graf N. Propofol versus midazolam/ketamine for procedural sedation in pediatric oncology. J Pediatr Hematol Oncol 2005;27:471-476.

15. Karapinar B, Yilmaz D, Demirağ K, Kantar M. Sedation with intravenous ketamine and midazolam for painful procedures in children. Pediatr Int 2006;48:146-151.

16. Ozdemir D, Kayserili E, Arslanoglu S, Gulez P, Vergin C. Ketamine and midazolam for invasive procedures in children with malignancy: a comparison of routes of intravenous, oral and rectal administration. J Trop Pediatr 2004;50:224-228.

17. Roback MG, Wathen JE, Bajaj L, Bothner JP. Adverse events associated with procedural sedation and analgesia in pediatric emergency department: a comparison of common parenteral drugs. Acad Emerg Med 2005;12:508-513.

18. Ozkan A, Okur M, Kaya M, Kaya E, Kucuk A, Erbas M, Kutlucan L, Sahan L. Sedoanalgesia in pediatric daily surgery. Int J Clin Exp Med 2013;6:576-582.

19. Migdady MI, Hayajneh WA, Abdelhadi R, Gilger MA. Ketamine and midazolam sedation for pediatric gastrointestinal endoscopy in the Arab world. World J Gastroenterol 2011;17:3630-3635.

20. Wood M. The use of intravenous midazolam and ketamine in pediatric dental sedation. SAAD Dig 2013;29:18-30.

21. Wathen JE, Roback MG, Mackenzie T, Bothner JP. Does midazolam alter the clinical effects of intravenous ketamine sedation in children? A double-blind, randomized, controlled, emergency department trial. Ann Emerg Med 2000;36:579-588.

22. Ramaiah R, Bhananker S. Pediatric procedural sedation and analgesia outside the operating room: anticipating, avoiding and managing complications. Expert Rev Neurother 2011;11:755-763. 